Pirineos, 153-154: 145 a 157, JACA; 1999

\title{
ACTIVITY RHYTHMS AND THE INFLUENCE OF SOME ENVIRONMENTAL VARIABLES ON SUMMER UNGULATE BEHAVIOUR IN ORDESA-MONTE PERDIDO NATIONAL PARK
}

\author{
A. AldeZABAL* I. Garin** \& R. García-GonZÁlez \\ Instituto Pirenaico de Ecología CSIC. Apdo. 64, 22700 Jaca (Spain) \\ * Dpto. de Agrosistemas y Producción Animal NEIKER. Berreaga 1, E-48160 Derio (Bizkaia) \\ Zoologiako Laborategia, Zientzi Fakultatea, Universidad del País Vasco. Apdo. 644, E-48080 Bilbo (Bizkaia)
}

SUMMARY.- We have studied daily activity rhythms and time-budgets of four large herbivores (cattle, sheep, goats and chamois) which form a multi-species grazing system in a summer pastoral unit of the Central Pyrenees. Also, the influence of some environmental variables (altitude, slope and plant cover) on the main activities has been appraised. Grazing is the activity to which most time is dedicated in all the species: cattle $48 \%$, sheep $53 \%$, goats $55 \%$ and chamois $68 \%$. Cattle is the species with the highest resting rate (41\%) and sheep is the species spends most time walking (35\%). Results suggest the existence of an inverse relationship between body size and grazing time. Cattle show two clear grazing peaks during the day at early morning and late evening. Contrary to this, sheep and chamois show a multimodal pattern, with some peaks for this activity throughout the day. Environmental factors clearly influence cattle and chamois activities. Sheep and goats show a less definite pattern in respect to environmental factors, probably because of their herded condition.

RESUMEN.- Se estudian los ritmos de actividad diarios y la distribución del tiempo entre diferentes actividades, de cuatro grandes herbivoros (vacas, ovejas, cabras y rebecos) que utilizan durante el verano la misma unidad pastoral (Puerto de Góriz, Parque Nacional de Ordesa) en el Pirineo Central. Asimismo, se determina la influencia de diversas variables ambientales (altitud, pendiente y cobertura vegetal) sobre la conducta de dichos rumiantes. El pastoreo es la actividad a la que más tiempo dedican todas las especies: vacas $48 \%$, ovejas $53 \%$, cabras $55 \%$ y rebe$\cos 68 \%$. El ganado vacuno es la especie que más tiempo dedica al descanso (41\%) y el ovino el que más tiempo emplea en desplazarse (35\%). Los resultados sugieren la existencia de una relación inversa entre tamaño corporal y tiempo dedicado al pastoreo, ya apuntada por otros autores. Vacas y cabras presentan dos periodos máximos de pastoreo a primeras horas de la mañana y al atardecer, mientras que ovejas y rebecos presentan varios máximos de pastoreo a lo largo del día. Vacas y rebecos muestran claras relaciones entre varios tipos de actividad y los factores ambientales, mientras que la relación es menos aparente para ovejas y cabras. 
RÉSUMÉ.- Nous avons etudié les rythmes d'activité journaliers ainsi que la distribution temporelle des différents types de comportement de quatre ongulés (vaches, brebis, chèvres et isards); ils utilisent la même unité pastorale (estive de Goriz) dans les Pyrénées Centrales, au Parc National d'Ordesa. Aussi nous avons evalué l'influence de diverses variables environnenmentales (altitude, pente et recouvrement végétal) sur le comportement des rumiants. Le pâturage devient l'activité prépondérante chez toutes les espèces: vaches $58 \%$, brebis $53 \%$, chèvres $55 \%$ et isards $68 \%$ du temps diurne. Les bovins passent plus de temps que les autres au repos (41\%) et les brebis dédient beaucoup de leur temps au déplacement (35\%). Ces résultats suggérent une relation inverse le poids vif et le temps du pâturage, phénomène déjà noté par d'autres. Bovins et caprins montrent deus périodes maximales de pâturage: le matin et la tombée du jour, tandis qu'ovins et isards présentent plusieurs pics du pâturage pendant la journée. Enfin bovins et isards montrent des relations significatives entre chacun des différents types de conduite et certains de l'environnement, tandis que ces rapports s'avèrent moins clairs pour les brebis et les caprins.

Key-words: Summer grazing, cattle, sheep, goat, chamois, daily activity, time budget, Pyrenees, Spain.

\section{Introduction}

Mountain areas, and the Pyrenees in particular, are suffering intense changes in soil and landscape use. Therefore, there is a greater need for compatibility between traditional livestock activities and new landscape uses. To this effect, detailed information is required regarding spatial use patterns of ungulates in mountain pasturelands, and factors affecting their behaviour.

A considerable number of studies have been carried out to determine livestock spatial use patterns and the environmental factors influencing them (SENFT et al., 1985a, 1985b; WARREN \& MYSTERUD, 1991; BAILEY, 1995; HOWERY et al., 1998). Nevertheless, there is a lack of quantitative data on the influence of these factors on livestock behaviour. Typically, livestock behaviour is divided in three main activity types: grazing, resting and moving (ARNOLD \& DUDZINSKI, 1978). These activities have important consequences, both for the landscape (spatial distribution, habitat and vegetation use) and for the animal itself (feeding and nutrition).

Environmental features of mountain pasturelands, such as rough topography and great variability of plant communities and grass cover, make up a patchy habitat where both territory use and animal behaviour are subjected to the influence of these ecological factors. It is an accepted pattern that grazing activity is affected to a greater degree by pasture conditions, while relief factors have greater influence on resting and moving activities (DUNCAN, 1983; SENFT et al., 1985a; GARCÍA-GONZÁLEZ et al., 1990). 
This study has two principal aims: a) to describe the activity rhythms of cattle, sheep, goats and Pyrenean chamois (Rupicapra pyrenaica, an autochtonous wild caprini locally named sarrio or isard); b) to determine the influence of the selected three variables (altitude, slope and plant cover) on the behaviour of these herbivores.

\section{Study Area}

Research was conducted in Ordesa and Monte-Perdido National Park, in the Central Pyrenees, within a pastoral unit called Puerto de Goriz. The supraforestal pastures of the National Park have been used for centuries as communal summer pastureland («puerto») for livestock grazing. Four species of domestic ungulates (sheep, goats, cattle and horses), comprising several different flocks and herds, use these pastures. The pastoral unit studied has a surface area of 6100 ha though in effect only 4280 ha are used. Pastures extend between altitudes of 1800 to $2500 \mathrm{~m}$. The climate is cool-continental, with cold winters and warm summers. Mean annual temperature is close to $5^{\circ} \mathrm{C}$ and mean annual precipitation is greater than $1600 \mathrm{~mm}$, with a high interannual variation which can range from $1300 \mathrm{~mm}$ to $3000 \mathrm{~mm}$. Calcareous upland pastures predominate and the location and development of plant communities vary basically depending on elevation and soil depth.

Ten broad vegetation units have been described in this area, among which we can outline the following: dense mesophilous pastures of Bromus erectus (Al. Mesobromion erecti) and a variant of Festuca paniculata (Asoc. ScorzoneroFestucetum spadiceae); dense swards of Nardus stricta (Al. Nardion strictae); acidophilous pastures of Festuca eskia on slopes (Al. Festucion eskiae); dense swards on deep and snow-covered soils (Al. Primulion intricatae); stony oromediterranean pastures on slopes and ridges (Al. Festucion gautieri and Al. Saponarion caespitosae); and the vegetation of permanently wet soils (Al. Caricion nigrae) as well as nitrophilous communities (Al. Rumicion alpini and Al. Polygonion avicularis). More details on the composition and structure of these communities can be found in ALDEZABAL (1997).

Livestock ascends to summer ranges on July $23 \mathrm{rd}$ and descends at the end of September or the beginning of October, with the first snows. The flock of sheep studied is composed of 3300 head, which are herded by two shepherds. Fifty goats also form part of the flock. A herd of 232 head of free-ranging cattle also grazed in the area. Horses were not surveyed because of their low numbers at present (only 5 heads in 1991). The mean stocking rate was 0.78 $\mathrm{LU} \times$ month/ha ( $\mathrm{LU}=$ Livestock Unit, that is, 1 cow of $500 \mathrm{Kg}$; conversions being calculated on the basis of metabolic weights). The traditional stocking rate in these pasturelands was three to four times higher than the present 
figures (ALDEZABAL et al., 1992). A population of Pyrenean chamois with 870 individuals was present in this National Park in 1991. Park rangers have estimated that 93 chamois inhabit the study area, and remain there from the end of spring to the month of November.

\section{Material and methods}

\subsection{Data gathering}

The present study formed part of a more extensive research project dealing with summer use of mountain pasturelands in Ordesa-Monte Perdido National Park (ALDEZABAL et al., 1992). Data were obtained during the summer of 1991 which was considered to be a drier and hotter summer than in previous years (1991 summer rainfall: $205.5 \mathrm{~mm}$; mean rainfall of 10 previous years: $367.6 \mathrm{~mm}$; min: $192 \mathrm{~mm}$; max: $643 \mathrm{~mm}$ ).

We recorded the activity of domestic goats, sheep, cattle and chamois during daylight hours over five days of August. Every 30 minutes up to 20 individuals of each species chosen at random were surveyed by the scansampling method (ALTMANN, 1974) and their behaviour was classified into three main types: grazing, resting and walking. Remaining activities such as suckling, fighting or courtship were grouped under the heading "other activities». As a whole, the number of observations per species reached 525 in goats, 1465 in sheep, 1952 in cattle and 669 in chamois. In addition, some topographical and environmental features were noted for the whole herd, such as aspect, slope degrees, altitude, plant cover, climatic conditions and human presence. Time was stated as Greenwich Mean Time (GMT).

Sheep and goats were kept in the fold for the night by the shepherds, so no grazing or moving activities took place. Although contradictory data exist regarding the nocturnal activity of cattle (GREEN \& BEAR, 1990; PINCHAK et al., 1991; STUTH, 1991), we assumed no night-time activity as was described by ARNOLD \& DUDZINSKI (1978) for cattle in mountain areas with great temperature variations. Chamois may show some night-time activity although during the summer there is likely to be twilight (HUTTER \& GLAUSER, 1974). In any case, the activity could not be recorded due to difficulties in following the chamois at night in mountainous areas (CIOFOLO \& BOISIER, 1992; BRUNO \& LOVARI, 1989).

\subsection{Data treatment}

We grouped the observations into one-hour intervals to represent the activity pattern of the four mentioned species. The proportion of animals engaged in a 
specific activity was taken to represent a percentage of the time devoted to this activity. However, as the number of individuals surveyed at hourly intervals was not similar, we used the proportion of individuals involved in each activity. type and hourly interval to estimate the proportion of observations undertaken in different activities during daylight hours. This avoids the bias of oversampling certain times of the day (BELOVSKY \& SLADE, 1986).

Using the Chi-squared test we analysed the dependence of grazing and resting behaviour on several environmental variables such as altitude, slope and plant cover. We searched for significant differences in the distribution of these activities along the gradient determined by these variables (ZAR, 1984; SIEGEL \& CASTELLAN, 1988). It must be noted that due to many nil values and expected values of less than 5 , the chi-squared test could not be carried out in a number of cases; in order to avoid this methodological constraint data was grouped into broader intervals when possible.

\section{Results}

It can be observed that cattle spend almost $89 \%$ of time grazing and resting. Grazing time makes up $48.3 \%$ of daylight activity (Figure 1), which is equivalent to $7 \mathrm{~h}$ /day during the $14.5 \mathrm{~h}$ of daylight in August. Moreover, cattle show two well-marked grazing peaks during the day (figure 2): one in the early morning, just after sunrise, and the other late in the evening. Grazing activity decreases at midday, although it does not disappear completely. The resting pattern is the inverse of the grazing one, increasing at midday.

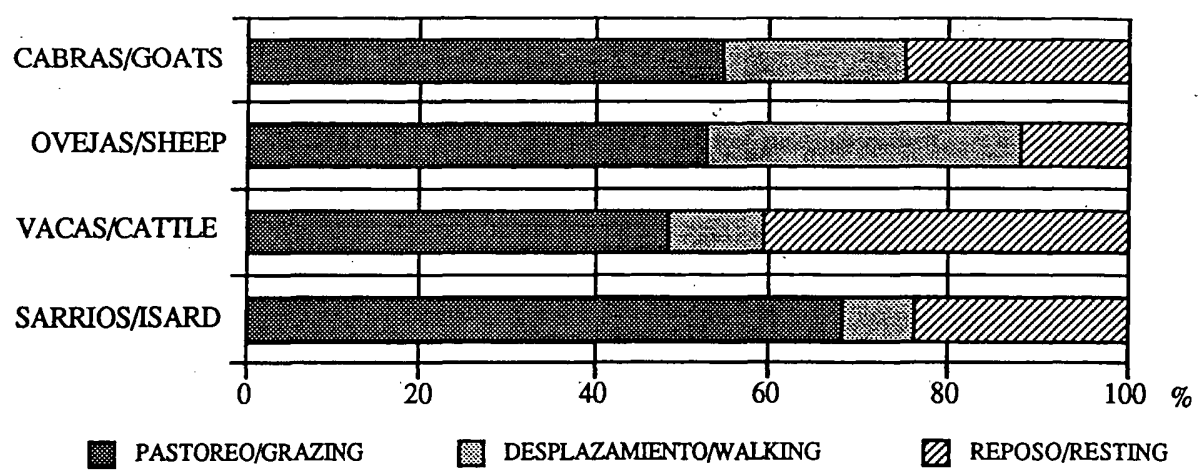

Figure 1. Temporal distribution of the main daylight activities during summer corresponding to each species.

Porcentaje del tiempo invertido en las principales actividades por cada especie en verano durante el tiempo diurno. 

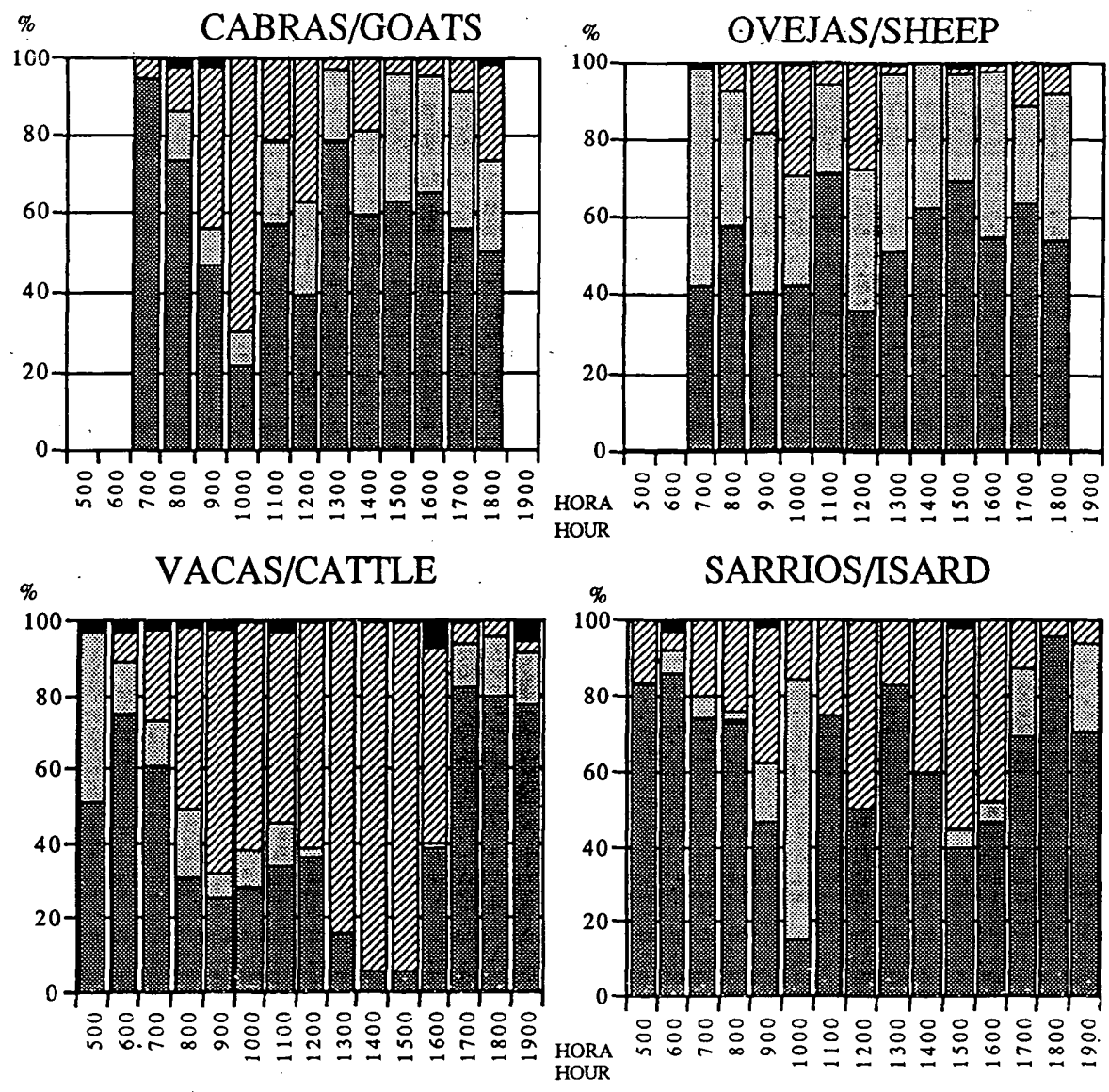

SARRIOS/ISARD

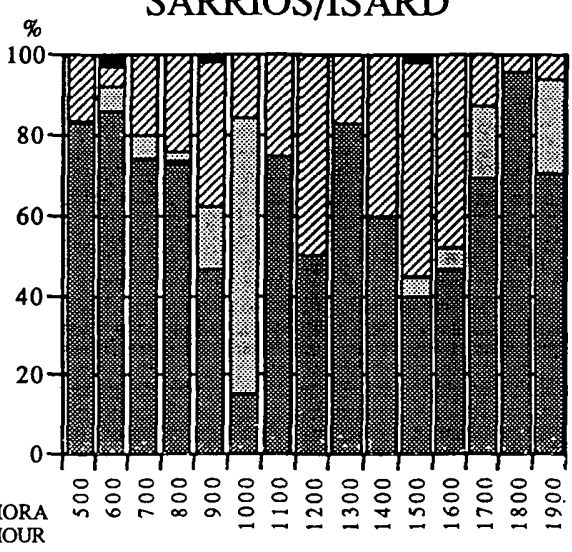

OTRAS ACTIVIDADES/OTHER ACTIVITIES

圈 DESPLAZAMIENTO/WALKING

Z REPOSO/RESTING

南 PASTOREO/GRAZING

Figure 1. Daylight distribution of the main activities of each species

Porcentaje del tiempo invertido en las principales actividades por cada especie durante las horas diurnas.

The total grazing and resting time in sheep is approximately $64.5 \%$ of daylight, of which $52.7 \%$ corresponds to grazing time (Figure 1). In this case, the grazing pattern in sheep is not bimodal (Figure 2). Sheep is the species which spends most time walking $(35.5 \%)$ in comparison with goats $(20.4 \%)$, cattle $(11.2 \%)$ or chamois $(7.8 \%)$. 
Goats spend almost $80 \%$ of day-time grazing and resting, of which $54.7 \%$ (or an equivalent of $7.9 \mathrm{~h} /$ day) is dedicated to grazing activity (Figure l). Goats show (Figure 2) clearer grazing peaks than sheep, although both form a part of the same flock and are equally managed by the shepherds.

Grazing and resting for chamois takes up $92 \%$ of the daylight, of which $68.4 \%$ (Figure 1) corresponds to grazing (almost $10 \mathrm{~h}$ /daylight). At least three clear grazing peaks appear in the activity rhythm (figure 2), and it is the species with the lowest walking time.

The distribution of grazing and resting activities along the gradient determined for the three environmental variables, altitude, slope, and plant cover (Table l), are different in each of the species $(\mathrm{p}<0.0 \mathrm{l})$. Only cattle seem to show a clear behavioural trend at the two altitudinal levels they occupy, with higher grazing rates at low altitudes, and longer resting periods at higher altitudes. Their activity distribution in relation to slope is similar to the distribution for altitude, i. e. grazing activity is greater in flat areas or smooth slopes and resting is more frequent in steeper areas $(\mathrm{p}<0.001)$; probably

\begin{tabular}{|c|c|c|c|c|c|c|c|c|c|c|c|c|c|}
\hline \multirow[t]{2}{*}{ Variable } & \multirow{2}{*}{$\begin{array}{l}\text { Intervalos } \\
\text { Intervals }\end{array}$} & \multicolumn{3}{|c|}{ Goats/cabras } & \multicolumn{3}{|c|}{ Sheep/ovejas } & \multicolumn{3}{|c|}{ Cattle/vacas } & \multicolumn{3}{|c|}{ Chamois/sarrio } \\
\hline & & $G$ & $R$ & $N$ & G & $R$ & & & $R$ & & G & $R$ & \\
\hline \multirow{7}{*}{$\begin{array}{c}\text { Altitude } \\
\text { Altitud }\end{array}$} & $1800-1900$ & 68 & 32 & 72 & 91 & 91 & 175 & \multirow{7}{*}{\multicolumn{3}{|c|}{$\begin{array}{ccc}63 & 37 & 860 \\
42 & 58 & 807\end{array}$}} & \multirow{7}{*}{$\begin{array}{l}77 \\
72\end{array}$} & \multirow{7}{*}{$\begin{array}{l}23 \\
28\end{array}$} & \multirow{7}{*}{$\begin{array}{l}291 \\
322\end{array}$} \\
\hline & $1900-2000$ & 88 & 12 & 60 & 881 & 122 & 208 & & & & & & \\
\hline & $2000-2100$ & 66 & 34 & 257 & 703 & 303 & 392 & & & & & & \\
\hline & $2100-2200$ & 100 & 0 & 11 & 100 & 04 & 40 & & & & & & \\
\hline & $2200-2300$ & 85 & 15 & 13 & 99 & $\begin{array}{ll}1 & 1\end{array}$ & 130 & & & & & & \\
\hline & $2300-2400$ & & & & & & & & & & & & \\
\hline & $2400-2500$ & & & & & & & & & & & & \\
\hline Slope & $0-5^{\circ}$ & 92 & 8 & 13 & 100 & $\begin{array}{ll}0 & 1\end{array}$ & 104 & & 40 & 957 & \multirow{3}{*}{74} & \multirow{3}{*}{26} & \multirow{3}{*}{613} \\
\hline \multirow[t]{2}{*}{ Pendiente } & $5-30^{\circ}$ & 81 & 19 & 393 & 802 & 208 & 826 & \multirow{2}{*}{\multicolumn{3}{|c|}{$42 \quad 58710$}} & & & \\
\hline & $30-60^{\circ}$ & 57 & 43 & 7 & 100 & $0 \quad 1$ & 15 & & & & & & \\
\hline \multirow{5}{*}{$\begin{array}{l}\text { Plant cover } \\
\text { Cobertura } \\
\text { vegetal }\end{array}$} & $0-25 \%$ & 100 & 0 & 15 & 100 & 07 & 70 & \multirow{5}{*}{\multicolumn{3}{|c|}{$\begin{array}{lll} & & \\
32 & 68 & 400 \\
75 & 25 & 580 \\
47 & 53 & 648\end{array}$}} & 67 & 33 & 277 \\
\hline & $25-50 \%$ & 0 & 0 & 0 & 683 & 324 & 47 & & & & 77 & 23 & 160 \\
\hline & $50-75 \%$ & 62 & 38 & 218 & 792 & 21,3 & 394 & & & & 65 & 35 & 60 \\
\hline & $75-95 \%$ & 78 & 22 & 147 & 792 & 213 & 315 & & & & 94 & 6 & 88 \\
\hline & $95-100 \%$ & 81 & 19 & 33 & 100 & $\begin{array}{ll}0 & 1\end{array}$ & 119 & & & & 82 & 18 & 28 \\
\hline
\end{tabular}

$G=$ Grazing/Pastando; $R=$ Resting/Reposando

Table 1. Percentage and number of animals $(\mathrm{N})$ by species grazing and resting in each established interval along environmental variables.

Porcentaje y número de animales $(N)$ pastando y reposando en cada uno de los rangos establecidos para cada variable ambiental en cada especie. 
because altitude and slope are correlated in our data series (Spearman Rank correlation, $\mathrm{p}<0.001)$. The patterns for goats and sheep seem very similar, probably because they are managed by the same shepherd and are in the same flock. Along the slope the distribution of grazing and resting again shows great similarities.

In the case of plant cover, we can see significant differential use of the different plant cover types by cattle and chamois depending on the activity type. Grazing is carried out in areas with high plant cover, whereas resting is carried out in areas with low and medium plant cover level. Again there is no clear-cut difference in trend, between goats and sheep, which have very similar patterns (grazing and resting, $\mathrm{p}>0.05$ ).

\section{Discussion}

A possible relationship between body size and grazing time in ruminants has been pointed out (BUNNELL \& GILLINGHAM, 1985; BELOVSKY \& SLADE, 1986; MYSTERUD, 1998), although some other factors (physiological constraints, biting rate, food availability, etc) may also be responsible for the variations on feeding time (NORTON, 1981). The present study was developed in a multigrazing system where all the herbivores fed only on grass, and the results suggest that grazing time increases as body size decreases (Figure 1), in agreement with BELOVSKY \& SLADE (1986) and BUNNELL \& GILLINGHAM (l. c.). Nevertheless the low number of animal species observed prevent us to obtain a statistical validation for this trend (mean body weight in $\mathrm{kg}$, minimum and maximum values are: 27.5 (20-35), 39.5 (34-45), 55 (45-65) and 400 (350-450) for chamois, sheep, goat and cattle respectively, ALDEZABAL et al., 1993).

The bimodal rhythm pattern in cattle is similar to that described by other authors (BOWNS, 1971; GLUESING et al., 1980; WARREN \& MYSTERUD, $l$. $c$.$) . Likewise, the overall grazing plus resting time, and estimated grazing$ time are similar to those described by HART et al. (1993).

There are many studies on activity of unherded sheep (BOWNS, 1971; GLUESING et al., 1980; WARREN \& MYSTERUD, l. c.). However, there are few studies on the activity rhythms of herded sheep in extensive systems (FAVRE, 1979; GARCÍA-GONZÁLEZ et al., 1990). In general, grazing time can vary and tends to be greater in unherded sheep (BOWNS, 1971; GLUESING et al., l. c.). According to a study carried out in the Alps, the grazing time was 6.5-7 h/day and $7.5 \mathrm{~h} /$ day for herded and unherded sheep respectively (FAVRE, l.c.). The fact that the surveyed sheep spent $7.6 \mathrm{~h} /$ day 
grazing might be due to the need to balance the energetic outlay caused by an increase in walking: $35 \%$ of the total time in our case, while BOWNS (1971) averaged $5 \%$ walking in unherded sheep.

In sheep and goats, which form the same mixed herd, a grazing increase was observed from 13.00h (GMT) onwards, which indicates that they grazed less in the morning than in the evening. Furthermore they did not show any clear behavioural pattern. The fact that the shepherd left its flock to roam free only 2 or 3 hours after sunrise, in order to avoid early morning grazing on wet grass, is comparable to the natural behaviour of free-ranging sheep, which did not graze the pasture while it was wet (BOWNS, l. c.). The adaptative significance of this behaviour could lie in the avoidance of parasitic infections and digestive troubles.

The multimodal behaviour pattern showed by chamois has also been observed in other wild ungulates (NORTON, 1981). Thus, the daily activity rhythm is similar to those described by other authors for the same species (PEPIN et al., 1991; BRUNO \& LOVARI, 1989; CIOFOLO \& BOISSIER, 1992), which suggests that grazing is the main daytime activity of the chamois, followed by resting, and finally change of location.

Regarding the influence of environmental factors on behaviour, time after sunrise and change in relative humidity has been pointed out as the most. important factors predicting the taking place of a given activity (ARNOLD \& DUDZINSKI, 1978; ROATH \& KRUEGER, 1982). It has been shown in the present study that environmental variables such as altitude, plant cover and slope can also play a significant role in the performance of any activity. Nevertheless, the influence is different depending on the species. The altitudinal distribution of behaviour follows a clear trend only in cattle: greater altitudes result in greater resting activity, to the detriment of grazing. The effect of slope is similar to that of altitude with more grazing on flat surfaces and more resting on steep hillsides. Probably, thermorregulation constraints (SENFT et al., 1985b) or fly harassment avoidance (DUNCAN COWTAN, 1980; SENFT et al., 1985b) caused the search for higher and steeper areas for resting. Steep hillsides, regardless of vegetation type occurring there, are not used by cattle, as has been pointed out in previous studies (ROATH \& KRUEGER, 1982; HART et al., 1991; PINCHAK et al., 1991).

Regarding vegetation cover, chamois and cattle rest more on low cover areas, whereas the grazing rate increases in higher plant cover areas. Probably, diet behaviour is related to the need to optimise intake with minimal energy loss (de MIGUEL et al., 1997) and, therefore, would agree with optimal foraging strategies already described by some authors (PYKE, 1984).

Sheep and goats do not show a clear distribution trend of grazing and resting activities along the gradient of any environmental variable. This may 
be due to their particular conditions of management, in which displacement activity plays an important role during all daily activity time intervals (Figure 2). Continuous movement throughout the day means that sheep and goats encounter a great variety of environmental situations. Even if sheep and goats were to have a particular environmental preference for the development of a specific activity, they soon move on and probably change their environmental situation due to the high environmental patchiness in mountains. It is probable that the temporal scale adopted in this study for the treatment of activity data (hourly intervals) is too long for the detection of environmental differences in the behaviour of these two species.

Acknowledgements. We would like to thank everybody who participated in the different parts and phases of this study, specially those who helped in the taking of field records. This study was developed within the frame of a CSICICONA co-operation project entitled «Livestock use of supraforestal pastures of the Ordesa-Monte Perdido National Park». The study was also partly supported by the Basque Government through two PhD grants. We thank Dr. S. Rebollo and an anonymous referee for their valuable comments on the manuscript, which significantly improved the final version of the article.

\section{References}

ALDEZABAL, A. (1997). Análisis de la interacción vegetación-grandes herbivoros en las comunidades supraforestales del Parque Nacional de Ordesa y Monte Perdido (Pirineo Central, Aragón). Tesis doctoral, Universidad del País Vasco.

ALDEZABAL. A., BAS, J., FILLAT, F., GARCÍA-GONZÁLEZ, R., GARIN, I., GÓMEZ, D. \& SANZ, J. L. (1992). Utilización ganadera de los pastos supraforestales en el Parque Nacional de Ordesa y Monte Perdido. Informe Final. Convenio ICONA-CSIC. Jaca-Huesca. (unpublished).

ALDEZABAL, A., GARIN, I. \& GARCÍA-GONZÁLEZ, R. (1993): Concentración de nitrógeno fecal en ungulados estivantes en los pastos supraforestales del Parque Nacional de Ordesa y Monte Perdido. Pastos, 23 (1): 101-114.

ALTMANN, J. (1974). Observational study of behavior: Sampling methods. Behaviour 49: 227-267.

ARNOLD, G. W. \& DUDZINSKY, M. L. (1978). Ethology of free-ranging domestic animals. Developments in animal and veterinary sciences, 2. Elsevier. Amsterdam. 
BAILEY, D. W. (1995). Daily selection of feeding areas by cattle in homogeneous and heterogeneous environments. Applied Animal Behaviour Science, 45: 183-200.

BELOVSKY, G. E. \& SLADE, J. B. (1986). Time budgets of grasslands herbivores: body size similarities. Oecologia, 70: 53-62.

BOWNS, J. E. (1971). Sheep behavior under unherded conditions on mountain summer ranges. Journal of Range Management, 24: 105-109.

BRUNO, E. \& LOVARI, S. (1989). Foraging behaviour of adult female Apennine chamois in relation to seasonal variation in food supply. Acta Theriologica, 34: 513-523.

BUNNELL, F. L. \& GILLINGHAM, M. P. (1985). Foraging behaviour: dynamics of dining out. In: HUDSON, R.J. \& WHITE, R.G. (eds.) Bioenergetics of Wild Herbivores, pp. 53-79. CRC, Boca Raton, Florida.

CIOFOLO, I. \& BOISSIER, M. (1992). Diurnal fluctuations in activity in the izard. Journal of Ethology, 10: 1-5.

DUNCAN, P. (1983). Determinants of the use of habitat by horses in a Mediterranean wetland. Journal of Animal Ecology, 52: 93-109.

DUNCAN, P. \& COWTAN, P. (1980). An unusual choice of habitat helps: camargue horses to avoid blood-sucking horse-flies. Biology of Behaviour 5: 55-60.

FAVRE, Y. (1979). Comportement des bovins et des ovins en alpage. In: INRA (ed.) Utilisation par les ruminants des pâturages d'altitude et parcours méditerranéens, pp. 863-886. Versailles.

GARCÍA-GONZÁLEZ, R., HIDALGO, R. \& MONTSERRAT, C. (1990). Patterns of time and space use by livestock in the Pyrenean summer ranges: a case study in the Aragon valley. Mountain Research and Development, 10: 241-255.

GLUESING, E. A., BALPH, D. F. \& KNOWLTON, F. F. (1980). Behavioral patterns of domestic sheep and their relationship to coyote predation. Applied Animal Ethology, 6: 315-330.

GREEN, R. A. \& BEAR, G. D. (1990). Seasonal cycles and daily activity patterns of rocky mountain elk. Journal of Wildlife Management, 54: 272-279.

HART, R. H., HEPWORTH, K. W., SMITH, M. A. \& WAGGONER, J. W. (1991). Cattle grazing behavior on a foothill elk winter range in southeastern Wyoming. Journal of Range Management, 44: 262-266.

HOWERY, L. D., PROVENZA, F. D., BANNER, R. E. \& SCOTT, C. B. (1998). Social and environmental factors influence cattle distribution on rangeland. Applied Animal Behaviour Science, 55: 231-244.

HUTTER, P. \& GLAUSER, M. (1974). Les chamois et les bouquetins. Ed. Payot. Laussanne. 
de MIGUEL, J. M., RODRÍGUEZ, M. A. \& GÓMEZ SAL, A. (1997). Determination of animal behavior-environment relationships by correspondence analysis. Journal of Range Management, 50: 85-93.

MYSTERUD, A. (1998). The relative roles of body size and feeding type on activity time of temperate ruminants. Oecologia, 113: 442-446.

NORTON, P. M. (1981). Activity patterns of Klipspringers in two areas of the Cape province. South African Journal of Wildlife Research, 11: 126-134.

PÉPIN, D., GONZALEZ, G. \& BON, R. (1991). Le Chamois et L'isard. Revue d'Ecologie (La Terre et la Vie) Suppl. 6: 111-153.

PINCHAK, W. E., SMITH, M. A., HART, R. H. \& WAGGONER, J. W. (1991). Beef cattle distribution patterns on foothill range. Journal of Range Management, 44: 267-275.

PYKE, G. H. (1984). Optimal foraging theory: a critical review. Annual Review of Ecology and Systematics, 15: 523-575.

ROATH, L. R. \& KRUEGER, W.C. (1982). Cattle grazing and behavior on a forested range. Journal of Range Management, 35: 332-338.

SENFT, R. L., RITTENHOUSE, L. R. \& WOODMANSEE, R. G. (1985a). Factors influecing patterns of cattle grazing behavior on shortgrass steppe. Journal of Range Management 38: 82-87.

SENFT, R.L., RITTENHOUSE, L.R. \& WOODMANSEE, R.G. (1985b): Factors influencing selection of resting sites by cattle on shortgrass steppe. Journal of Range Management, 38: 295-299.

SIEGEL, S. \& CASTELLAN, N. J. J. (1988). Nonparametric statistics for the behavioral sciences. McGraw-Hill, Inc. USA.

STUTH, J. W. (1991). Foraging Behavior. In: Heitschmidt, R.K. and Stuth, J.W. (eds) Grazing Management. An Ecological Perspective, pp. 65-83. Timber Press. Portland.

WARREN, J. T. \& MYSTERUD, I. (1991). Summer habitat use and activity patterns of domestic sheep on coniferous forest range in southern Norway. Journal of Range Management, 44: 2-6.

ZAR, J. H. (1984). Biostatistical Analysis. Prentice-Hall Int. Ed. New Jersey. 


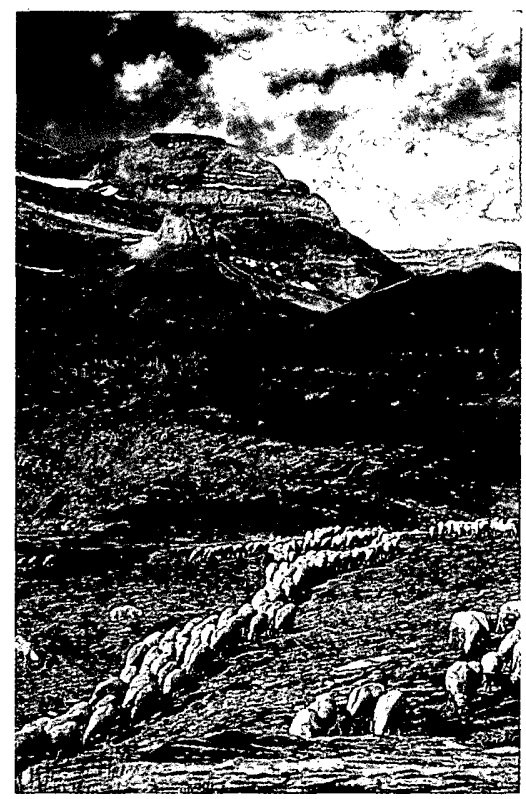

Photograph 1. One of the studied sheep flocks walking by the Sierra Custodia hill-sides $(2100 \mathrm{~m})$; at the bottom Torre de Góriz. Sheep spend 35\% of their time in walking activity. Photo F. Fillat. Imagen de uno de los rebaños de ovejas estudiados desplazándose por las laderas de Sierra Custodia; al fondo la Torre de Góriz. El ganado ovino invierte un $35 \%$ de su tiempo en la actividad de desplazamiento. Foto F. Fillat.

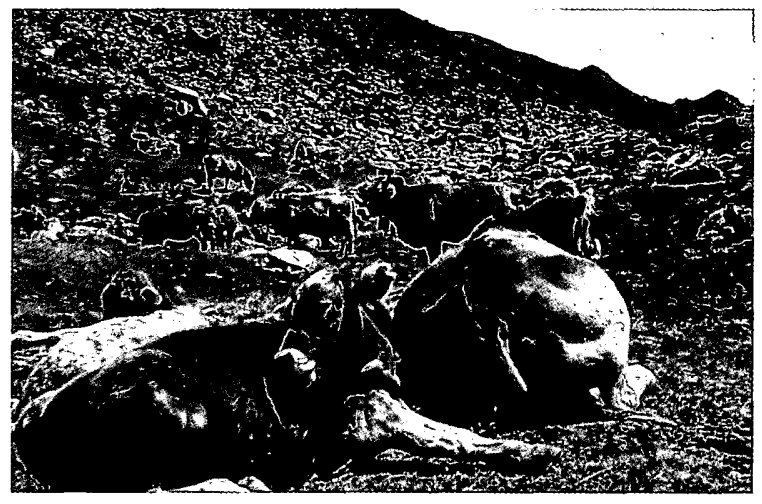

Photograph 2. Cattle herd in resting activity in Montaña de Sensa (c. $1900 \mathrm{~m}$ ) summer pastureland. Cattle is the species that most time spents in resting activity, with a $41 \%$ of their summer time budget. Photo F. Fillat.

Grupo de vacas en descanso en el puerto de la Montaña de Sensa. El ganado vacuno es la especie que más invirtió en este tipo de conducta, totalizando un $41 \%$ de su tiempo. Foto F. Fillat. 